Г.А. Медведєв ${ }^{1}$, Т.І. Карнаух ${ }^{1}$

${ }^{1}$ Державний науково-дослідний інститут авіації, Київ

\title{
ОБГРУНТУВАННЯ ТЕХНІЧНОГО ОБРИСУ ТА ОСНОВНИХ ВИМОГ ДО МОДЕРНІЗОВАНИХ (ПЕРСПЕКТИВНИХ) КОМПЛЕКСІВ ЗАСОБІВ ЗАХИСТУ ТАКТИЧНИХ ЛІТАКІВ
}

У статті представлена актуальність оснащення військових літальних апаратів (ЛА) новим поколінням бортових систем захисту, які об'єднуються у єдиний комплекс. В иьому контексті розглядається досвід сучасних збройних конфліктів, в тому числі антитерористичної операчії на Сході Украӥни. Аналізується перелік завдань авіаційних засобів радіоелектронної боротьби, типи радіоелектронних перешкод та об’єкти дій для постановки перешкод бортовими засобами захисту. Визначаються світові тенденції розвитку комплексів індивідуального радіоелектронного захисту ЛА. Здійснюється аналіз функиіональних можливостей та технічних характеристик итатних систем захисту тактичних літаків Повітряних Сил Збройних Сил Украӥни, визначаються їх основні недоліки.

3 урахуванням проведеного аналізу обгрунтовано технічний обрис перспективного комплексу індивідуального захисту тактичного літака та сформовано підхід до визначення вимог щзодо його основних тактико-технічних характеристик. Розглянуто можливі шляхи створення такого комплексу.

Ключові слова: радіоелектронна боротьба, індивідуальний захист літаків, станція постановки активних радіоелектронних перешкод, станиія попередження про радіолокаційне опромінення, система попередження про ракетну атаку, хибна иіль, бортовий комплекс оборони.

\section{Вступ}

Постановка проблеми. Актуальність питання оснащення військових літальних апаратів (ЛА) бортовими системами захисту визначається умовами ведення сучасної збройної боротьби, коли застосування авіації пов'язано, насамперед, з надактивною протидією 3 боку системи протиповітряної оборони (ППО) та винищувальної авіації противника. Насиченість сучасного театру бойових дій радіотехнічними засобами (РТ3), призначеними для виявлення повітряних об'єктів та цілевказання системам озброєння, досягла того рівня, коли застосування авіації без належного забезпечення засобами радіоелектронної боротьби (РЕБ) для вирішення бойових та інших задач практично втрачає свою ефективність [1]. Це зумовлює актуальність оснащення літальних апаратів сучасними засобами РЕБ. Загальною особливістю РЕБ на сучасному етапі $\epsilon$ різке зростання iї ролі у всіх ланках управління [2, с. 10; 3, с. 9], дедалі більше перенесення зусиль у тактичну ланку, в сферу загальновійськового і повітряного бою.

Бортові системи та пристрої РЕБ функціонально об'єднаються у єдиний комплекс та пов'язуються загальними алгоритмами i централізованими обчислювальними системами [4, с. 368...372]. Призначення та склад такого комплексу повинен визначатися бойовими завданнями відповідного ЛА, його бойовими можливостями та способами бойових дій. В більш широкому розумінні іноді вводять поняття бортового комплексу оборони (БКО), як сукупності компонентів РЕБ та вогневого ураження засобів противника [5, с. 92...104].

Тенденція щодо постійного зростання воєннотехнічного рівня РТЗ ППО та винищувальної авіації ще більше підсилює актуальність оснащення тактичних літальних апаратів сучасними індивідуальними і груповими засобами РЕБ, висуває додаткові вимоги до їх технічного вдосконалювання. Передові у військово-технічному відношенні держави розглядають це як пріоритетне завдання [6, 7].

Останні збройні конфлікти сучасності доказали на практиці потребу в оснащенні тактичних літаків сучасними системами радіоелектронного захисту, тактико-технічні характеристики та технічні можливості яких відповідали б воєнно-технічному рівню засобів ППО противника [8...10].

Особливо гостро ця необхідність проявила себе на початку антитерористичної операції на Сході України, коли більшість втрат штурмової i бомбардувальної авіації була зумовлена саме відсутністю або застарілістю систем радіоелектронного захисту.

Починаючи з 2014 року, в Міністерстві оборони України та Генеральному штабі Збройних Сил України ведеться активна робота $з$ удосконалення комплексів захисту ЛА різних класів. Прийнято 
відповідні рішення та сформовано оперативнотактичні вимоги до окремих систем захисту, а також їх бортових комплексів. Українські підприємства мають науково-технічні напрацювання за окремими напрямками даної галузі. У військовому відомстві розглядаються також пропозиції відомих іноземних розробників щодо оснащення вітчизняних військових ЛА сучасними високотехнологічними зразками засобів захисту.

Мета цієї статті - на основі аналізу штатних засобів захисту тактичних літаків та їх об'єктів протидії, основних напрямів і світових тенденцій розвитку бортових комплексів РЕБ визначити раціональну архітектуру бортового комплексу захисту тактичного літака та основні вимоги до його компонентів. Зазначений технічний обрис може розглядатися як при модернізації штатних бортових комплексів, так і при розробці нових зразків для перспективних тактичних літаків Повітряних Сил Збройних Сил України.

\section{Виклад основного матеріалу}

Вирішення поставленої задачі 3 позицій системного підходу необхідно розпочати з аналізу в цілому переліку завдань авіаційних засобів радіоелектронної боротьби, типів радіоелектронних перешкод та об'єктів дій для постановки перешкод бортовими засобами захисту.

Системи та засоби РЕБ, що входять до складу бортового радіоелектронного обладнання літаків тактичної авіації, призначені, в основному, для вирішення задач індивідуального захисту. Питання, які стосуються групового захисту ЛА, знаходяться поза межами розгляду даної статті.

Однією 3 причин, стимулюючих розвиток систем індивідуального захисту, є переобладнання літаків, що знаходяться на озброєнні багатьох країн світу, при розробці яких не використовувались технології “стелс". Такі ЛА потребують додаткового захисту від ракет класу “поверхня-повітря” i “повітря-повітря”. Крім того, навіть якщо при створенні літака і були використані елементи такої технології, наявність зброї на зовнішніх підвісках при вирішенні ряду задач підвищує рівень його демаскуючих ознак.

Основними бойовими завданнями бортового комплексу індивідуального захисту тактичного літака є:

одночасне виявлення випромінювання радіолокаційних станцій (РЛС) у робочому діапазоні хвиль, класифікація РЛС та оцінка рівня загроз у реальному масштабі часу;

вибір найбільш небезпечних РЛС;

виявлення авіаційних та зенітних керованих ракет, що атакують ЛА, визначення швидкості зближення атакуючої керованої ракети (КР) 3 носієм, визначення часу підльоту КР, видачу виконавчого сигналу для приведення в дію комплексу захисту ЛА від атак КР в автоматичному режимі;

постановка активних перешкод потенційно небезпечним РЛС літаків-винищувачів і зенітноракетних (зенітно-гарматних) комплексів, активним i напівактивним радіолокаційним головкам самонаведення (ГСН) ракет;

постановка пасивних перешкод РЛС цілевказання та радіолокаційної головки самонаведення зенітних та авіаційних ракет; постановка перешкод інфрачервоним (тепловим) ГСН зенітних та авіаційних ракет.

Відповідно цілями перешкод бортових засобів захисту повинні бути $[11$, с. $21 \ldots 33 ; 12$, с. 18$]$ :

РЛС наведення зенітних керованих ракет; бортові корабельні та авіаційні РЛС управління зброєю;

станції гарматного наведення зенітних артилерійських комплексів (ЗАК);

радіолокаційні (активні, напівактивні) ГСН ракет класів “повітря-повітря" і “земля-повітря"; теплові головки самонаведення ракет класу “повітря-повітря" та ракет переносних зенітноракетних комплексів.

Основними типами радіоелектронних перешкод, які застосовуються в сучасних комплексах захисту ЛА, $\epsilon$ маскуючі (шумові загороджувальні, ковзаючі і прицільні за частотою або комбіновані) та імітуючі перешкоди (копії зондуючих сигналів, відвідні за дальністю, за швидкістю, за напрямком). При цьому найбільш ефективними для індивідуального захисту ЛА вважаються імітуючі перешкоди “у відповідь”, які представляють собою копії зондуючих сигналів РЛС управління зброєю i радіолокаційних ГCH керованих зенітних та авіаційних ракет, відвідні за дальністю, швидкістю та напрямком [13, с. 47...56; 14 , с. $347 \ldots 352]$.

Для формування вимог до нових (модернізованих) засобів захисту тактичних літаків доцільним $\epsilon$ проведення аналізу аналогічних за функціональним призначенням систем, які застосовуються (розробляються) в провідних авіаційних країнах. Радіотехнічна частина більшості сучасних закордонних комплексів індивідуального радіоелектронного захисту ЛА включає до свого складу: станцію постановки активних радіоелектронних перешкод (ASPJ - Airborne Self Protection Jammer); станцію попередження про радіолокаційне опромінення (RWR - Radar Warning Receiver); систему попередження про пуск ракет або про ракетну атаку (MAW - Missile Approach Warning); пристрій (пристрої) викиду хибних цілей (CMDS - Countermeasure Dispenser System); 
буксирувану на оптико-волоконному кабелі радіолокаційну хибну ціль (FOTD - fibre-optic towed decoy); єдину систему управління та індикації (для забезпечення роботи комплексу в повністю автоматичному режимі). Основні тактико-технічні характеристики (ТTX) більшості відомих радіоелектронних засобів виявлення та цілевказання, а отже, відповідно і закордонних авіаційних засобів РЕБ [15]:

частотний діапазон - 2..18 ГГц;

зона огляду за азимутом - $360^{\circ}$ (авіаційних засобів $\left.- \pm 95^{\circ}\right)$;

зона огляду за кутом місця - до $85^{\circ}$;

дальність виявлення цілі типу “винищувач” -

16...500 км (авіаційних засобів - до 200 км);

час реакції - $4 . .15 \mathrm{c}$;

ширина діаграми спрямованості антени $-0,5 \ldots 4^{\mathrm{o}}$; кількість супроводжуваних цілей - до 1000 (авіаційних - до 24).

Проведений аналіз дозволяє виділити такі основні тенденції розвитку в цій предметній галузі:

розширення частотного діапазону як систем попередження про радіолокаційне опромінення, так і засобів радіоелектронного подавлення (від 6...12,5 ГГц до $2 . .20$ ГГц, а в перспективі - до 1...40 ГГц);

покращення точності визначення пеленгу на джерела радіовипромінювання та розширення секторів захисту ЛА;

збільшення кількості радіоелектронних засобів, що одночасно виявляються та подавляються;

підвищення швидкодії, а саме: зменшення часу аналізу прийнятого сигналу та часу генерації сигналу перешкод за рахунок використання повністю цифрових технологій обробки сигналів;

забезпечення радіоелектронної розвідки та постановки перешкод сучасним РЕ3, у тому числі і системам зі складними сигналами;

глибока інтеграція засобів захисту в бортове радіоелектронне обладнання ЛА 3 використанням спільних шин обміну даними, баз даних та обчислювальних потужностей;

підвищення ступеню “інтелектуальності" авіаційних засобів РЕБ, яке полягає, насамперед, в забезпеченні комплексного аналізу радіоелектронної обстановки, формуванні варіантів можливих протидій $з$ забезпеченням можливості вибіркового подавлення РЕ3 противника та можливістю функціонування складових комплексу захисту ЛА в повністю автоматичному режимі;

виконання комплексів захисту або їх окремих складових у варіанті універсальних для різних типів ЛА підвісних контейнерів РЕБ;

удосконалення елементної бази та програмного забезпечення 3 широким використанням нових технологій в області створення РЕЗ, принципів “відкритої архітектури” та комерційно доступних компонентів, що зумовлює розширення функціональних можливостей засобів захисту, підвищення тактико-технічних характеристик, покращення експлуатаційних і зниження масогабаритних та вартісних показників.

3 точки зору формування вимог до нових (або модернізованих) систем і пристроїв перспективного комплексу індивідуального захисту дуже важливим $€$ визначення основних недоліків штатних засобів захисту, які знаходяться на озброєнні тактичних літаків Повітряних Сил Збройних Сил України. Проведений детальний аналіз їх функціональних можливостей та технічних характеристик дозволяє прийти до висновку, що зазначені засоби не повністю відповідають сучасному військовотехнічному рівню та вимогам до таких систем, а саме за такими показниками:

за частотним діапазоном ВЧ сигналів, що сприймаються та імітуються;

за просторовою роздільною здатністю станцій попередження про опромінення (за кутом місця та азимутом);

за можливістю виявлення та подавлення сучасних РЛС зі складними сигналами (зі швидкою перебудовою робочої частоти);

за часом реакції (аналізу характеристик РE3, що виявляються, та генерації сигналу перешкод);

за кількістю РЕЗ, які одночасно виявляються та подавляються, а також за обсягом бази даних характеристик джерел радіовипромінювання;

за можливістю виявлення та створення перешкод РЕ3 розробки колишнього СРСР та Російської Федерації;

за можливістю уніфікованого використання на різних типах ЛА.

Окрім цього, не всі типи вітчизняних тактичних літаків мають у складі свого обладнання всі необхідні компоненти комплексу захисту (наприклад, щодо попередження про пуск ракет).

3 урахуванням проведеного аналізу сучасних вимог, узагальнення світового досвіду та тенденцій розвитку бортових засобів захисту ЛА, а також науково-технічних напрацювань промисловості, технічний обрис перспективного комплексу індивідуального захисту тактичного літака має включати такі основні складові:

станцію попередження про радіолокаційне опромінення;

систему попередження про ракетну атаку (систему попередження про пуск ракет);

станцію активних радіоелектронних перешкод; комбіновані пристрої викиду хибних цілей;

центральний обчислювач, органи контролю, управління та індикації комплексу.

При цьому повинно бути забезпечено взаємодію (координацію роботи) засобів захисту ЛА 
на основі використання центрального цифрового обчислювача комплексу.

Вимоги до основних тактико-технічних характеристик такого перспективного комплексу повинні забезпечити усунення визначених вище недоліків штатних бортових засобів захисту, як 3 точки зору окремих параметрів (частотного діапазону, роздільної здатності, часу реакції, кількості засобів противника, які одночасно виявляються та подавляються, тощо), так і з точки зору сукупності функціональних можливостей комплексу (уніфікованості для різних типів ЛА та можливості протидії сучасним РЕЗ противника).

Одним 3 ключових компонентів комплексу захисту ЛА, який суттєвою мірою визначає рівень його технічної досконалості, є станція постановки активних перешкод. Характерним технічним рішенням, що застосовується при створенні більшості таких сучасних станцій, є використання технології DRFM (Digital Radio Frequency Memory) цифрового запам'ятовування зондуючого сигналу на високій частоті [16], яка передбачає генерацію сигналу перешкод “у відповідь" на основі використання цифрової копії зондуючого сигналу з внесеними до неї хибними параметрами цілі. На даний час роз-робники засобів захисту ЛА пропонують новітні підходи до створення станцій постановки активних радіоелектронних перешкод, які насамперед базуються на генеруванні високоякісних енергоефективних перешкод - копій зондувальних сигналів “у відповідь”. Зазначені засоби захисту дозволяють створювати ефективні перешкоди навіть сучасним РЛС управління зброєю та радіолокаційним ГСН 3 моноімпульсними кутомірними каналами та складними зондувальними сигналами.
Застосування комплексу індивідуального захисту тактичного літака у визначеному складі та 3 передбаченими характеристиками забезпечить високу ефективність виконання завдань (зниження ймовірності ураження ЛА противником). Надання більш детальних чисельних значень оцінок ефективності потребує проведення додаткового математичного моделювання, зокрема стосовно результатів створення перешкод по окремих каналах (кутомірному, вимірювання швидкості, вимірювання дальності).

\section{Висновки}

Обгрунтований технічний обрис та основні вимоги до комплексу індивідуального радіоелектронного захисту ЛА можуть бути використані як при модернізації штатних засобів захисту літаків Повітряних Сил Збройних Сил України, так і при створенні сучасного бортового комплексу оборони перспективного тактичного літака.

Вирішення зазначеної задачі можливе як силами підприємств вітчизняної промисловості, так i 3 залученням іноземних компаній - відомих світових розробників авіаційних засобів РЕБ. Також можливим $\epsilon$ варіант формування міжнародної кооперації.

Оснащення високотехнологічними системами радіоелектронного захисту сучасних та перспективних літаків $\epsilon$ ключовим елементом як забезпечення суттєвого підвищення їх військовотехнічного рівня з загальнонаукової точки зору, так i радикального покращення характеристик живучості ЛА з точки зору практичної доцільності.

\section{Список літератури}

1. Черниш О.М., Тищук С.О., Шолохов С.М. Основи формування нової ідеології ведення радіоелектронної боротьби у війнах і збройних конфліктах майбутнього // Наука і оборона, 2006. - № 4. - С. 48-51.

2. Леньшин А.В. Бортовые комплексы радиоэлектронной борьбы / Учебное пособие. - Воронеж: ВУНЦ ВВС "BBA", 2016. - $508 \mathrm{c}$.

3. Осипов В.Ю., Ильин А.П., Фролов В.П., Кондратюк А.П. Радиоэлектронная борьба. Теоретические основы / Учебное пособие для вузов. - Петродворец: ВМИРЭ, 2006. - 302 с.

4. Куприянов А.И., Шустов Л.Н. Радиоэлектронная борьба. Основы теории. - М.: Вузовская книга, 2011. - 800 с.

5. Современная радиоэлектронная борьба. Вопросы методологии / Под ред. В.Г. Радзиевского. - М.: Радиотехника, 2006. $-424 \mathrm{c}$.

6. Перунов Ю.М., Мацукевич В.В., Васильев А.А. Зарубежные радиоэлектронные средства / Под ред. Ю.М. Перунова. В 4-х книгах. Кн. 2: Системы радиоэлектронной борьбы. - М.: Радиотехника, 2010. - 352 с.

7. Павлов С.И. Авиационные средства радиоэлектронной борьбы вооруженных сил США // Зарубежное военное обозрение, 2019. - №6. - С. 62-69.

8. Иванов И. Содержание и роль радиоэлектронной борьбы в операциях XXI века // Зарубежное военное обозрение, 2011. - № 1. - С. 14-20.

9. Евграфов В. Развитие авиационных средств радиоэлектронной борьбы и их применение в современных вооруженных конфликтах // Зарубежное военное обозрение, 2011. - № 2. - С. 60-65.

10. Цыганок А.Д. Применение сил и средств РЭБ в войнах и конфликтах XXI века [Електронний ресурс]. - Режим доступу: https://nvo.ng.ru/wars/2019-09-20/6_1062_reb.html. 
11. Леньшин А.В. Бортовые системы и комплексы радиоэлектронного подавления. - Воронеж: ИПЦ "Научная книга", 2014. - 590 с.

12. Добыкин В.Д., Куприянов А.И., Пономарев В.Г., Шустов Л.Н. Радиоэлектронная борьба. Цифровое запоминание и воспроизведение радиосигналов и электромагнитных волн / Под общ. ред. А.И. Куприянова. - М.: Вузовская книга, 2009. - 360 с.

13. Защита радиолокационных систем от помех. Состояние и тенденции развития / Под ред. А.И. Канащенкова и В.И. Меркулова. - М.: Радиотехника, 2003. - 416 с.

14. Борисов Е.Г., Евдокимов В.И. Высокоточное оружие и борьба с ним: Учебное пособие. - СПб.: Изд. “Лань”, 2013. $-496 \mathrm{c}$.

15. Ярош С.П. Аналіз характеристик сучасних засобів радіоелектронної боротьби авіаційного базування // Системи озброєння і військової техніки. - Харків: ХУПС ім. І. Кожедуба, 2014. - № 3(39). - С. 72-80.

16. Ростов А.А., Рахоцкий Д.А. Применение технологии DRFM для формирования высокоэффективных сигналоподобных помех // Материалы международной научной конференции “Информационные технологии и системы - 2014". - Минск: изд. БГУИР, 2014. - С. 310-311.

Надійшла до редколегії 20.11.2021

Схвалена до друку 30.11.2021

Відомості про авторів:

\section{Медведсв Геннадій Анатолійович}

старший науковий співробітник

Державного науково-дослідного інституту авіації, Київ, Україна

https://orcid.org/0000-0002-1045-2380

\section{Карнаух Тетяна Іванівна}

науковий співробітник

Державного науково-дослідного інституту авіації, Київ, Україна

https://orcid.org/0000-0002-0216-2949
Information about the authors:

\section{Gennadii Medvediev}

Senior Researcher

of State Research Institute of Aviation, Kyiv, Ukraine

https://orcid.org/0000-0002-1045-2380

\section{Tetiana Karnaukh}

Researcher Associate

of State Research Institute of Aviation,

Kyiv, Ukraine

https://orcid.org/0000-0002-0216-2949

\title{
SUBSTANTIATION OF TECHNICAL FACE AND BASIC REQUIREMENTS FOR MODERNIZED (PROSPECTIVE) COMPLEXES OF SELF-PROTECTION EQUIPMENT FOR TACTICAL AIRCRAFT
}

\author{
G. Medvediev, T. Karnaukh
}

The article presents the actuality of equipping military aircraft with a new generation of airborne self-protection systems, which will be combined into a single complex. In this context, the experience of modern armed conflicts, including the antiterrorist operation in the east of Ukraine, is considered. The tasks of aircraft electronic warfare hardware and objects of its interference are analyzed. The world tendencies of development of the aircraft individual electronic self-protection complexes are determined. The analysis of functional capabilities and technical characteristics of Ukrainian Air Force self-protection systems is carried out, their main shortcomings are determined.

Taking into account the conducted analysis, the technical face of a prospective individual self-protection complex of a tactical aircraft has been substantiated and an approach to determining the requirements for its basic features has been formed. The complex may include the following components: radar warning receiver, missile approach warning, airborne self-protection jammer, countermeasure dispenser system as well as computing, controlling and indicating devices. Interaction (coordination of work) of aircraft protection components should be ensured based on the use of the central digital computer of the complex. Possible ways to create such a complex are considered. The use of an individual protection complex for a tactical aircraft in a determined composition and with the specified characteristics will ensure high efficiency in performing missions (reducing the probability of an aircraft being hit by the enemy).

Keywords: electronic warfare, individual self-protection of aircraft, radio electronic interference, active electronic jamming station, radar warning receiver, missile approach warning, false target. 